\title{
The Eumyarion (Mammalia, Rodentia, Muridae) assemblage from Sandelzhausen (Miocene, Southern Germany): a test on homogeneity
}

\author{
Hans de Bruijn
}

Received: 1 August 2006/Accepted: 10 April 2007/Published online: 13 February 2009

(C) The Author(s) 2009. This article is published with open access at Springerlink.com

\begin{abstract}
A large sample of Eumyarion cheek teeth $(N=569)$ from the Early/Middle Miocene boundary locality Sandelzhausen (MN5, Southern Germany), type locality E. bifidus Fahlbusch, 1964, is studied. It is concluded that this collection contains two species: E. bifidus and E. weinfurteri Schaub and Zapfe, 1953. The similarity in size and morphology of the cheek teeth of these two species is so great that only the M1 and M2 can be recognised with certainty. Eumyarion bifidus seems to be a descendant of E. orhani de Bruijn et al., 2006 from the Early Miocene (MN3) of Southwestern Anatolia and is therefore considered to be an immigrant into Central Europe.
\end{abstract}

Keywords Rodentia - Muridae - Eumyarion ·

Dental analyses

Kurzfassung Dieser Arbeit liegt ein reichhaltiges Material von Backenzähnen von Eumyarion $(N=569)$ aus dem Grenzbereich Unter-/Mittelmiozän der Fundstelle Sandelzhausen (MN5, Süddeutschland), der Typlokalität der Art E. bifidus Fahlbusch, 1964 zugrunde. Es können zwei Arten nachgewiesen werden, E. bifidus und E. weinfurteri Schaub and Zapfe, 1953. Die Backenzähne der beiden Arten sind sich in Größe und Morphologie so ähnlich, dass nur die M1 und M2 sichere systematische Bestimmungen zulassen. Eumyarion bifidus scheint ein Abkömmling der Art E. orhani de Bruijn et al., 2006 aus dem Untermiozän (MN3) Südwest-Anatoliens zu sein und wird deshalb als Einwanderer in Zentral-Europa angesehen.

H. de Bruijn $(\bowtie)$

Department of Earth Sciences, University of Utrecht,

3508 TA Utrecht, The Netherlands

e-mail: hdbruijn@geo.uu.nl
Schlüsselwörter Nagetiere - Muridae - Eumyarion . Zahnmorphologie-Analyse

\section{Introduction}

Representatives of the genus Eumyarion Thaler 1966 share a specific combination of primitive dental characters (protoloph and metaloph transverse in M1 and M2, anterior arm of protocone of the M1 well developed, posterior arm of the hypoconid usually present in the $\mathrm{m} 1$ ) that distinguish them from other Miocene cricetids. The origin of the genus is not known because the oldest record from the lowermost Miocene of Anatolia seems to document its immigration into that area. Among the overwhelmingly diverse cricetids from Eurasia there seem to be two genera that have close phylogenetic ties with Eumyarion: (1) Anomalomys, which presumably is a descendant of E. intercentralis De Bruijn and Saraç 1991, and (2) Mirrabella de Bruijn et al. 2007, which may share a common ancestor with Eumyarion.

Identification of the formally named Eumyarion species is difficult because there seem to be no overall evolutionary trends in the development of the dental morphology and the individual variation in size and morphology within monospecific assemblages is large. The dental characters of the oldest species known (E. carbonicus de Bruijn and Saraç 1991, MN1-2, Anatolia) are basically similar to the ones in the youngest species [E. leemanni (Hartenberger 1965), MN9, SE Spain and central Europe]. The publication of larger collections of isolated teeth from single localities during the last two decades has contributed considerably to our notion of the individual variation within species, but has also, over and again, raised doubts about the homogeneity of these associations. As a result the status of those 
species names that were defined on the basis of small collections has remained unsettled. In this context the large new collection of Eumyarion teeth from Sandelzhausen [type locality E. bifidus Fahlbusch 1964 (Fahlbusch 2003)] is of special interest because it allows testing the heterogeneity of the association suggested by Wu (1982) and Schötz (1993). The questionable presence of more than one species of Eumyarion with overlapping morphology and size in one locality is by no means restricted to Sandelzhausen, but seems to be the rule in central European Early to Middle Miocene (MN4-MN6) localities. In contrast, the assemblages from Southwestern Europe seem homogeneous, while the ones from the Lower Miocene MN1-MN3 from Anatolia contain usually two (de Bruijn and Saraç 1991) and in one case even three (de Bruijn et al. 2006) species that clearly differ in size as well as in morphology.

In order to avoid confusion about the meaning of species names as used here, the available names are briefly reviewed below. We follow Fahlbusch (1964) and consider E. helveticus (Schaub 1925) a junior synonym of $E$. medius (Lartet 1851). The definition of three "subspecies" of Eumyarion in the fissures of Neudorf (Devínská Nová Ves, Slovakia) by Schaub and Zapfe (1953) has caused a confusion that continues to the present day. Engesser (1972) and Fejfar (1974) agree in considering the subspecies E. helveticus helveticus Schaub and Zapfe 1953 synonymous with E. latior Schaub and Zapfe 1953, but differ in their evaluation of the specimens that are the hypodigm of E. latior and E. weinfurteri. Engesser (1972) and de Bruijn and Saraç (1991) argue that the few somewhat smaller and simpler teeth that are the basis of E. weinfurteri can be expected to be well inside the range of the poorly known variation of the species E. latior. This decision would make E. weinfurteri a junior synonym of E. latior. However, Fejfar (1974), Engesser et al. (1981), Bolliger (1992), Schötz (1993) and Daxner-Höck (1998) maintain the name $E$. weinfurteri because they have homogeneous associations of Eumyarion teeth that are definitely smaller than the type material of E. latior and fit the size of E. weinfurteri. We follow Schötz (1993) who suggested to tentatively maintain the species name weinfurteri for associations of "small" Eumyarion teeth [i.e. from Dolnice, Ořechov (both Czechia), Aliveri (Greece) and Massendorf (Germany)] until the homogeneity of the collection from Neudorf (Devínská Nová Ves, Sovakia) is demonstrated. This leaves us with five European and three Anatolian species names for the medium-sized Eumyarion group of species. These are: E. medius (=E. helveticus), E. weinfurteri $(=$ E. candeloni Bulot 1979), E. latior $(=$ E. helveticus helveticus), E. bifidus, E. leemanni, E. carbonicus de Bruijn and Saraç 1991, E. montanus de Bruijn and Saraç 1991 and E. orhani de Bruijn et al. 2006.
E. valencianum (Daams and Freudenthal 1974) remains a nomen dubium because the few specimens known from its type locality Buñol (Spain) can neither be clearly distinguished from, nor synonymised with, those of the poorly documented $E$. weinfurteri and $E$. latior.

This investigation is based on material from the vertebrate fossil site Sandelzhausen, which is located in the Bavarian North Alpine Foreland Basin (Southern Germany) near the town of Mainburg, about $70 \mathrm{~km}$ north of Munich. The limnofluvial deposits of Sandelzhausen belong to the Upper Freshwater Molasse. Heissig (1997) referred the fauna of Sandelzhausen to the European Mammal Unit MN5 (Badenian), which approximately corresponds to an absolute age of $16 \mathrm{Ma}$. Based on recent bio-, litho- and magnetostratigraphic investigations the stratigraphic position of the locality Sandelzhausen is situated at, or very close to, the Early/Middle Miocene boundary (Karpatian/Badenian boundary) (Moser et al. 2009).

The Eumyarion material from Sandelzhausen

The material studied is housed in the collection of the Bayerische Staatssammlung für Paläontologie und Geologie in Munich (BSPG). The material is registered under the complete inventory numbers BSPG 1959 II xxxx; due to lack of space, in the following only the last number of the complete inventory number is listed. Upper molars are indicated as M1, M2, M3, lower ones as $\mathrm{m} 1$, $\mathrm{m} 2, \mathrm{~m} 3$.

Eumyarion bifidus: M1-M2 (7041), M2-M3 (7169 and 5502); M1 (7042, 7043-7049, 7052-7068, 7071-7077, 5500, 5501 and 9552-9560, 9562-9589); M2 (7170, 7171, 7173, 7175-7207, 7209, 7210, 7212-7220, 7222-7225, 9592-9608, 9610-9613, 9615-9617, 9619-9622, 96249626).

Eumyarion weinfurteri: M1 (7050, 7051, 7069, 7070, 7078, 7079, 7080, 9251, 9561); M2 (7172, 7174, 7208, 7211, 7221, 9590, 9591, 9609, 9618, 9623).

Eumyarion bifidus or weinfurteri: M3 (72747295,10270-10281, 10784-10797, 11000-11099); m1-m3 (6916), m1 (6917-6996, 6000-6005, 7006-7008, 94369481); m2 (7090-7168, 5504, 13071, 9482-9532, 9614); m3 (7226-7273, 10232-10269).

A peculiarity of the Sandelzhausen collection of the, mostly isolated, Eumyarion cheek teeth is that lower teeth are much better represented than the upper teeth (329 against 240) and that third molars are underrepresented (57 M3 against $98 \mathrm{M} 2$ and $83 \mathrm{~m} 3$ against $130 \mathrm{~m} 2$ ). These deviations from the numbers expected are considered to be due to collecting bias.

Since the dental morphology and the size of individual teeth within each tooth category show a, for one cricetid 


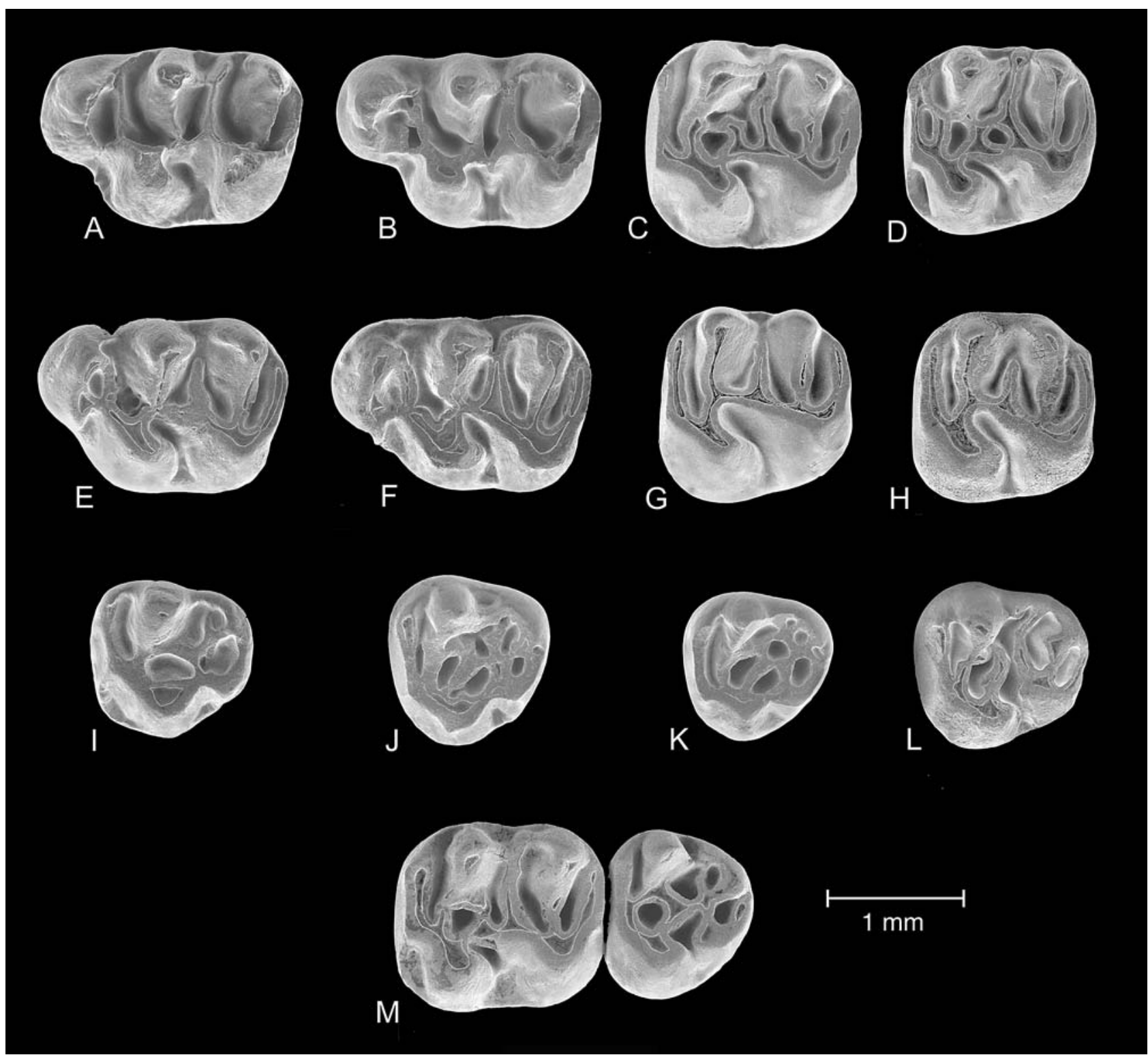

Fig. 1 Upper molars of Eumyarion from the Miocene (MN5) of Sandelzhausen (Southern Germany). Eumyarion bifidus: a (9554) and b (9552), M1; c (9613) and d (7218, inverse), M2; m (5502), M2, M3. Eumyarion weinfurteri: e (7051, inverse) and $\mathbf{f}$ (7069, inverse), M1; g

species, unusually large range of variation, it has been suggested by Fahlbusch (1964), Wu (1993), and Schötz (1993) that the assemblage contains a mixture of two species. Before deciding really to test the heterogeneity suggested, Fahlbusch and the author independently separated the M1 into two groups on the basis of morphology differences. After it appeared that the content of our groups were largely identical it was decided to test the hypothesis that the collection contains two species by checking whether or not the size of the specimens correlates with a few selected morphological characters. The characteristics chosen are:
(9618) and h (9623), M2. Eumyarion bifidus or weinfurteri: i (10278, inverse), $\mathbf{j}$ (7280), $\mathbf{k}$ (10271), and $\mathbf{l}$ (10276, inverse), M3. All teeth are figured as left specimens; right specimens are indicated by "inverse"

Upper cheek teeth (Fig. 1):

M1 The shape of the anterior-lingual sinus. Lingual spur of the anterocone: absent $=\mathrm{A}$, present $=\mathrm{B}$. Connection between the mesoloph and the metacone: present $=\mathrm{A}$, absent $=\mathrm{B}$.

Connection between the paracone spur and the mesoloph: present $=\mathrm{A}$, absent $=\mathrm{B}$.

M2 The configuration of the protoloph: double $=\mathrm{A}$, single $=$ B.

Connection between the metacone and the mesoloph: present $=\mathrm{A}$, absent $=\mathrm{B}$. 


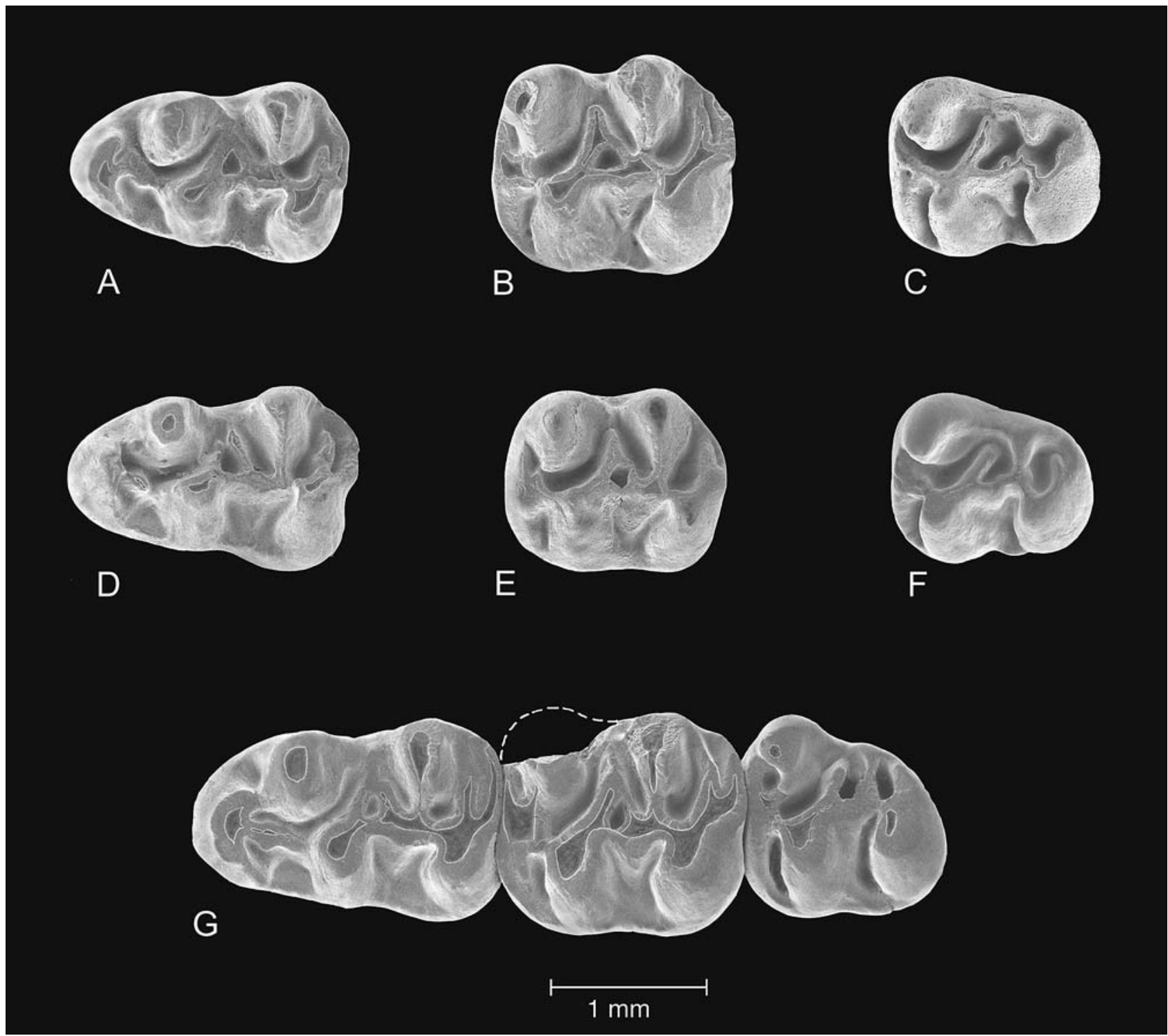

Fig. 2 Lower molars of Eumyarion from the Miocene (MN5) of Sandelzhausen (Southern Germany). Eumyarion bifidus or weinfurteri: a (6939) and d (6936), m1; b (9490) and e (9489), m2; c (7231)

Connection between the paracone spur and the mesoloph: present $=\mathrm{A}$, absent $=\mathrm{B}$.

M3 Number of lingually situated enamel lakes: two or more $=\mathrm{A}$, one $=\mathrm{B}$.

Lower cheek teeth (Fig. 2):

m1 The configuration of the posterior arm of the hypoconid: present $=\mathrm{A}$, absent $=\mathrm{B}$.

Connection between the posterior arm of the protoconid and the mesolophid: present $=\mathrm{A}$, absent $=\mathrm{B}$.

$\mathrm{m} 2$ The configuration of the posterior arm of the hypoconid: present $=\mathrm{A}$, absent $=\mathrm{B}$.

Connection between the posterior arm of the protoconid and the mesolophid: present $=\mathrm{A}$, absent $=\mathrm{B}$. and $\mathbf{f}(7235), \mathrm{m} 3 \cdot \mathbf{g}(6916), \mathrm{m} 1-\mathrm{m} 3$ of a large specimen represents most probably E. bifidus. All teeth are figured as left specimens; right specimens are indicated by "inverse"

m3 Posterior arm of the hypoconid: present $=\mathrm{A}$, absent $=$ B.

The configuration of the mesolophid: present $=\mathrm{A}$, absent $=\mathrm{B}$.

The combination of the coded morphology characteristics as defined above and the size of individual teeth (Figs. 3 and 4) shows that the BBB, BAB and BAA morphologies of the M1 (solid symbols in Fig. 3a) cluster rather nicely because these are, apart from the notable exceptions of nos. 552 and 580, shorter and wider than the specimens with the ABB, ABA, AAB and AAA morphologies (open symbols). The recheck of the morphology of the specimens 552 and 580 shows that no. 552 really 

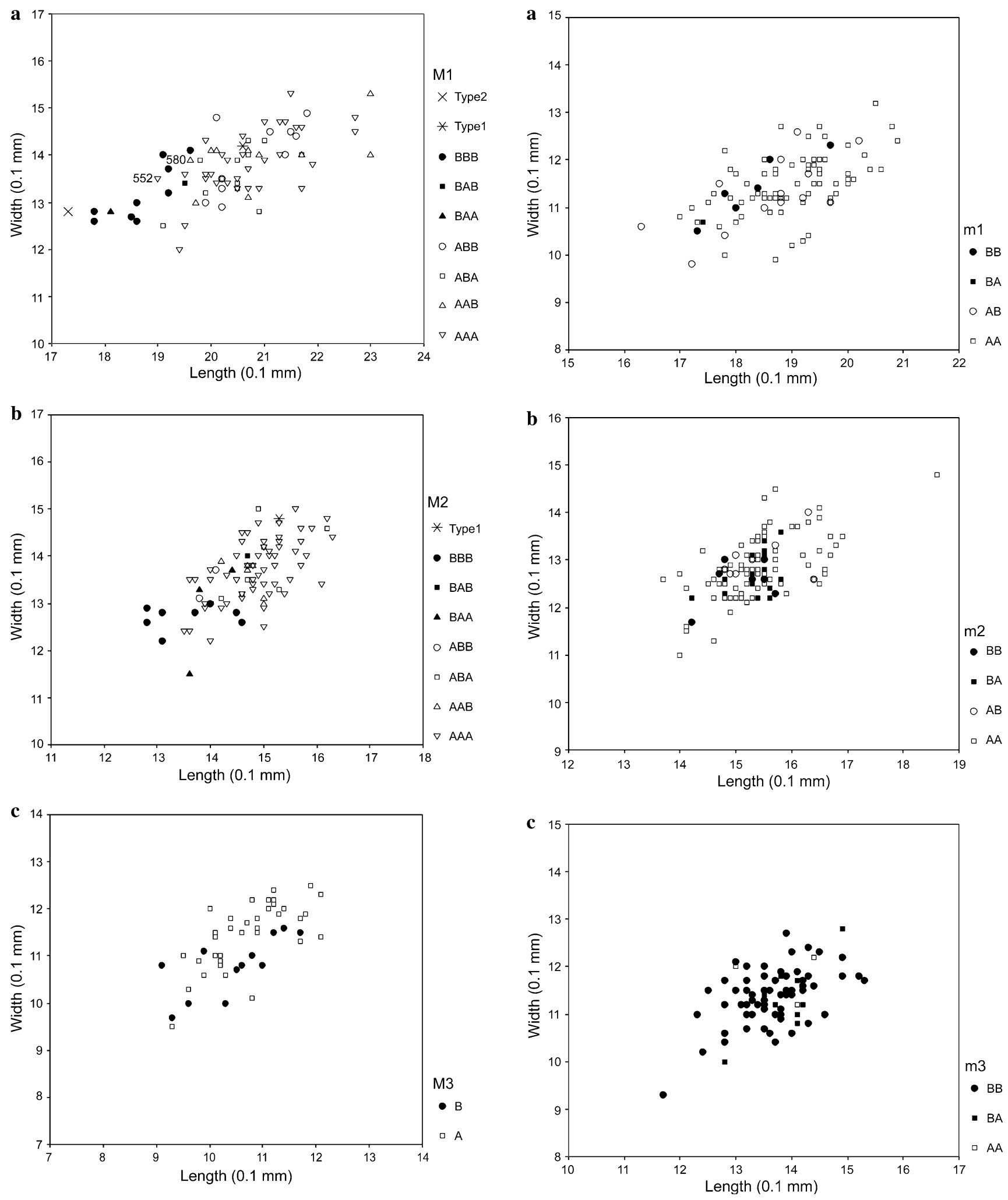

Fig. 3 Length/width scatter diagram of all upper molars of Eumyarion from Sandelzhausen. a M1, b M2, c M3. For the meaning of the different symbols see text. The holotype of E. weinfurteri (type 2, M1) and of E. latior (type 1, M1 and M2) have been added for

Fig. 4 Length/width scatter diagram of all lower molars of Eumyarion from Sandelzhausen. a $\mathrm{m} 1, \mathbf{b} \mathrm{m} 2, \mathbf{c} \mathrm{m} 3$. For the meaning of the different symbols see text 
shows the AAA type whereas no. 580 is difficult to assign to a specific category. The clustering of specific morphologies is less clear for the M2 (Fig. 3b), although the BBB, $\mathrm{BAB}$ and BAA morphologies (solid symbols) are again on average smaller than the specimens with the $A B B, A B A$, $\mathrm{AAB}$ and AAA morphologies (open symbols). In the M3 (Fig. 3c), a tooth that shows less morphological characteristic due to its variable degree of reduction, the clustering of the B types gets lost.

Our interpretation of Fig. 3a is that there are in fact two species of Eumyarion present in the Sandelzhausen collection. The M1 of these species can, with the exception of one single specimen, be identified on the basis of the shape of the anterocone alone. This means that about $90 \%$ of the M1 belong to E. bifidus and that about $10 \%$ show the morphology that is shared by E. weinfurteri and E. latior. Since the size of the holotype M1 of E. weinfurteri is smaller than that of E. latior and the cluster of specimens from Sandelzhausen with the E. weinfurteri and E. latior morphology is intermediate between the two holotypes, the choice for allocating our specimens remains ambiguous (Fig. 3a). This observation supports my earlier decision to synonymise $E$. weinfurteri with $E$. latior and suggests that size difference alone is not sufficient to characterise species. Nevertheless we maintain the name weinfurteri (sensu Schötz 1993) for reasons given above.

The diagram of the M2 (Fig. 3b) shows the specimens with a double protoloph (an E. bifidus characteristic) with open symbols and the ones with one single protoloph indicated by closed symbols. The size overlap between these two categories is large, but the smaller specimens again have the E. weinfurterillatior morphology. The question of whether or not all the M2 of E. bifidus have a double, or incipiently double, protoloph can be answered affirmatively, because, once again, about $90 \%$ of the total number of specimens show this character.

The diagram of the M3 (Fig. 3c) shows that the size of the specimens with two lingual enamel lakes (=a double protolophule) indicated by open symbols and the ones with one lake only matches very well. In contrast to the situation in the M1 and M2 about 25\% of the M3 have a E. weinfurterillatior morphology. This probably means that a limited number of the M3 of $E$. bifidus have lost one protoloph. As a consequence, these specimens cannot be identified on the species level.

The diagrams (Fig. 4) of the $\mathrm{m} 1, \mathrm{~m} 2$ and $\mathrm{m} 3$ show no clustering of specific morphotypes, so the lower cheek teeth of the two species cannot be distinguished. It may be expected, however, that the six $\mathrm{m} 1$ without the posterior arm of the hypoconid and possibly a few of the smaller specimens that have the posterior arm of the protoconid not connected to the mesolophid represent $E$. weinfurteri. The diagram of the $\mathrm{m} 2$ shows one very large outlier. This tooth shows the modal morphology of what are thought to be E. bifidus specimens, so there is no reason to exclude it from this species.

\section{Conclusions}

There are two species of Eumyarion present in the Sandelzhausen association: E. bifidus and an, on average, somewhat smaller species with a simpler dental pattern for which we tentatively employ the name E. weinfurteri. The only teeth of these two species that can be distinguished with confidence are the M1 and M2. Since the dentitions of medium-sized Eumyarion species do not show a consistent change through time, the reconstruction of phylogenetic lineages on the basis of the available record is hypothetical. A recent study on an Early Miocene (MN3) mammal fauna from Southwestern Anatolia (de Bruijn et al. 2006) suggests that E. bifidus most probably is a descendant of E. orhani and an immigrant from the Middle East, not an evolutionary stage of an "European" lineage. The occurrence of two species of Eumyarion with very similar dental morphology and size in a large number of Central European localities suggests that each of these was adapted to a specific food source occurring in central Europe in the same biotope. The fauna elements as well as the sedimentary environments associated with Eumyarion finds in general suggest that this biotope was a wetland environment.

Acknowledgments I thank the late Dr. V. Fahlbusch (Munich) for entrusting the Eumyarion collection from Sandelzhausen to me and for discussions and my colleague K. Hordijk (Utrecht) for making the scatter diagrams and for his patience while teaching me how to use a computer. The SEM photographs and the plates were made by W. den Hartog (Utrecht). M. Hugueney (Lyon) and W. Wessels (Utrecht) are gratefully acknowledged for reviewing the manuscript of this paper.

Open Access This article is distributed under the terms of the Creative Commons Attribution Noncommercial License which permits any noncommercial use, distribution, and reproduction in any medium, provided the original author(s) and source are credited.

\section{References}

Bolliger, T. 1992. Kleinsäugerstratigraphie in der Miozänen Hörnlischüttung (Ostschweiz). Documenta Naturae 75: 1-296.

de Bruijn, H., E. Ünay, G. Sarac, and G. Klein Hofmeijer. 1987. An unusual new Eucricetodontine from the Lower Miocene of the eastern Mediterranean. Proceedings of the Koninklijke Nederlandse Akademie van Wetenschappen 90(2): 119-132.

de Bruijn, H., L.W. van den Hoek Ostende, and S.K. Donovan. 2007. Mirrabella, a new name for the genus Mirrabella de Bruijn et al. 1987 (Mammalia), preoccupied by Mirrabella Emeljanov 1982 (Insecta). Contributions to Zoology 76(4): 279-280. 
de Bruijn, H., and G. Saraç. 1991. Early Miocene rodent faunas from the eastern Mediterranean area. 1. The genus Eumyarion. Proceedings of the Koninklijke Nederlandse Akademie van Wetenschappen B 94(1): 1-36.

de Bruijn, H., S. Mayda, L.W. Hoek Ostende, T. van den Kaya, and G. Saraç. 2006. Small mammals from the Early Miocene of Sabuncubeli (Manisa, S.W. Anatolia, Turkey). Beiträge zur Paläontologie 30: 57-87.

Bulot, C. 1979. Un nouvel Eumyarion (Rodentia, Mammalia) du Miocène de Bézian près de La Romieu (Gers). Bulletin de la société d' Histoire Naturelle de Toulouse 114(3-4): 373-381.

Daams, R., and M. Freudenthal. 1974. Early Miocene Cricetidae (Rodentia, Mammalia) from Buñol (Prov. Valencia, Spain). Scripta Geologica 24: 1-16.

Daxner-Höck, G. 1998. Wirbeltiere aus dem Unter-Miozän des Lignit-Tagebaues Oberdorf (Weststeirisches Becken, Österreich), 7. Rodentia. Annalen des Naturhistorischen Museumsin Wien 99A: 139-162.

Engesser, B. 1972. Die obermiozäne Säugetierfauna von Anwil (Baselland). Tätigkeitsberichte der Naturforschenden Gesellschaft Baselland 28: 35-363.

Engesser, B., A. Matter, and M. Weidmann. 1981. Stratigraphie und Säugetierfaunen des mittleren Miozäns von Vermes (Kt. Jura). Eclogae Geologicae Helvetiae 74(3): 893-952.

Fahlbusch, V. 1964. Die Cricetiden der Oberen Süsswasser-Molasse Bayerns. Bayerische Akademie der Wissenschaften, Mathematisch-Naturwissenschaftliche Klasse, Abhandlungen 118: 1-135.

Fahlbusch, V. 2003. Die Miozäne Fossil-Lagerstätte Sandelzhausen. Die Ausgrabungen 1994-2001. Zitteliana 43: 109-121.

Fejfar, O. 1974. Die Eomyiden und Cricetiden (Rodentia, Mammalia) des Miozäns der Tschechoslowakei. Palaeontographica A146: $100-180$.

Hartenberger, J.L. 1965. Les Cricetidae (Rodentia) de Can Llobateres (Néogène d' Espagne). Bulletin Société Géologique de France 7: 487-498.

Heissig, K. 1997. Mammal faunas intermediate between the reference faunas of MN4 and MN6 from the Upper Freshwater Molasse of
Bavaria. In Actes du Congrès BiochroM'97. Mémoires et Travaux de l'E.P.H.E., vol. 2, eds. J.-P. Aguilar, S. Legendre, and J. Michaux, 537-546. France: Institut de Montpellier

Lartet, E. 1851. Notice sur la colline de Sansan, suivi d'une récapitulation des diverses espèces d'animaux vertebrés fossiles, trouvés soit à Sansan, soit dans d'autres gisements du terrain Miocène dans le bassin sous-Pyrénéen, 45, Auch: J. A. Portes

Moser, M., G.E. Rössner, U.B. Göhlich, M. Böhme, and V. Fahlbusch. 2009. The fossil lagerstätte Sandelzhausen (Miocene; southern Germany): history of investigation, geology, fauna and age. In Fossil lagerstätte Sandelzhausen (Miocene, southern Germany): Contributions to the fauna, Paläontologische Zeitschrift, vol. 83, issue 1, eds. G.E. Rössner, and U.B. Göhlich, 000-000

Schaub, S. 1925. Die Hamsterartigen Nagetiere des Tertiärs und ihre lebenden Verwandten. Eine systematisch-odontologische Studie. Abhandlungen der Schweizerischen Palaeontologischen Gesellschaft 45: 5-111.

Schaub, S., and H. Zapfe. 1953. Die Fauna der Miozänen Spaltenfüllung von Neudorf an der March, Simplicidentata. Sitzungsberichte der Österreichische Akademie der Wissenschaften, Mathematisch Naturwissenschaftliche Klasse Abt. 1 162(3): 181-215.

Schötz, M. 1993. Zwei Hamsterfaunen (Rodentia, Mammalia) aus der niederbayerischen Molasse. Mitteilungen der Bayerischen Staatssammlung für Paläontologie und Historische Geologie 33: 155-193.

Thaler, L. 1966. Les rongeurs fossiles du Bas-Languedoc dans leurs rapports avec l'histoire des faunes et la stratigraphie du Tertaire d'Europe. Mémoires du Muséum National d'Histoire Naturelle, nouvelle série C 42: 3-284.

Wu, W. 1982. Die Cricetiden (Mammalia, Rodentia) aus der Oberen Süsswasser-Molasse von Puttenhausen (Niederbayern). Zitteliana 9: 37-80.

Wu, W. 1993. Neue Gliridae (Rodentia, Mammalia) aus untermiozänen (orleanischen) Spaltenfüllungen Süddeutschlands. Documenta Naturae 81: 1-149. 